\title{
Resistant Risk Assessment in the Insecticide Resistant Strains of Predatory Mite, Neoseiulus (=Amblyseius) longispinosus (Evans)
}

\author{
G. Sugeetha $^{1 *}$, N.S. Pankaja ${ }^{2}$, D.S. Janardhan ${ }^{3}$ and J. Mahadeva ${ }^{4}$ \\ ${ }^{1}$ Entomology, ${ }^{2}$ Plant Pathology, ${ }^{3}$ Agricultural Extension, ${ }^{4}$ Forestry and Environmental \\ Sciences, College of Agriculture, V. C. Farm, Mandya, India \\ *Corresponding author
}

\section{A B S T R A C T}

In vivo experiment was conducted by utilizing Neoseiulus longispinosus, a promising and potential predator of the spider mite, Tetranychus urticae. N. longispinosus is subjected to the insecticides (monocrotophos and dicofol) selection pressure to ingrain resistance

Keywords

Risk assessment, Insecticide, Predatory mite

Article Info

Accepted:

04 November 2018

Available Online:

10 December 2018 development. It was seen that the realized heritability $\left(\mathrm{h}^{2}\right)$ for the monocrotophos resistant population was 0.09 and 0.16 for generations $F_{0}$ to $F_{5}$ and $F_{10}$ to $F_{20}$ generations, respectively and realized heritability $\left(\mathrm{h}^{2}\right)$ for dicofol resistant population was 0.01 and 0.04 for the $F_{0}$ to $F_{5}$ and $F_{10}$ to $F_{20}$ generations, respectively. It was analysed that the $h^{2}$ value estimated at the end of six generations for monocrotophos selected population $\left(F_{0}\right.$ to $\left.F_{5}\right)$ was 1.8 times less than that of $F_{10}$ to $F_{20}$ generations and it was four times less for dicofol resistant population at the end of six generations when compared to $F_{10}$ to $F_{20}$ generations. This indicates that a high level of resistance to monocrotophos and dicofol can only be realized after long periods of selections (10 generations) in the laboratory reared populations of phytoseiid mite, Neoseiulus longispinosus. The degree of dominance was estimated and it was found that the monocrotophos resistant strain of $N$. longispinosus had $-0.52,-0.58,-0.96,-0.98$, and -0.97 for $5^{\text {th }}, 10^{\text {th }}, 20^{\text {th }}, 30^{\text {th }}$ and $40^{\text {th }}$ generations and the degree of dominance for dicofol resistant strain was -1 for all the generations. This indicated that the degree of dominance of insecticide resistance is completely recessive.

\section{Introduction}

The Spider mites belonging to the family Tetranychidae are the serious acarine pests on agricultural and horticultural crops. This mite has been reported infesting over 200 species of crop plants (Perry et al., 1998). Among horticultural crops, the spider mites are known to cause serious infestation on vegetable crops, plantation crops, flower crops and ornamental crops both in the field as well as in the protected environment. The loss caused by spider mites is related to the population level and stages of infestation. The yield reduction of 13.64 and 31.09 per cent at Bangalore and Varanasi, respectively was estimated due to the red spider mite (Anonymous. 1991). On flowers and ornamentals, mites are primarily an aesthetic concern, but they can kill plants if populations become very high on annual plants (Godfrey, 2011). In order to contain these spider mites, organochlorines, 
organophosphates and carbamates were widely used. Due to heavy selection pressure of acaro-insecticides, the spider mites gained insecticide resistance and these insecticides became ineffective in containing the pest. Acaro- insecticide resistance in the spider mites is a remarkable intrinsic potential for the rapid evolution of the resistance (van Leeuwen et al., 2010). Besides insecticide resistance, the application of insecticides eliminated the potential predators of the spider mites. Among the several predatory mite species, $N$. longispinosus was found widely distributed in almost all horticultural crops and they have a intimate association with the spider mite population. By considering integrated pest management (IPM) as key approach to modern plant protection (Hoy, 2011), developing an insecticide resistant predatory mites will be effective against the target pests and also compatible with the acaroinsecticides will reduce the number insecticidal application creating a safer environment to humans and other beneficial non target organisms in the field and protected environmental conditions.

The phytoseiid, N. longispinosus is a promising and potential predator of the spider mite, T. urticae. Since, the spider mites have developed high resistance to several insecticides biological control with $N$. longispinosus would be effective if it is tolerant / resistant to the chemicals used against the pest mites. In order to predict the rate of development of resistance in $N$. longispinosus in response to pesticide application, one has to study and understand the resistance risk assessment or realized heritability.

\section{Materials and Methods}

Two insecticides namely dicofol, an organochlorine and monocrotophos, an organo phosphorus compound were used for the insecticide resistant studies. Potters spray tower method was followed. The resistance to these two chemicals was induced in two different sets of the laboratory susceptible strain of phytoseiid mites, $N$. longispinosus. Initially, the susceptible strain was exposed to a concentration that produced $70 \%$ mortality. After 24 hour of treatment, the survivors were shifted to a fresh leaf bit containing spider mites. The concentration of insecticides was increased in an arithmetic progression after every generation and the mortality was recorded 24 hour after each treatment. Likewise, the selection of susceptible laboratory population to monocrotophos and dicofol respectively were maintained separately taking care to avoid mixing of the two populations.

Bioassay was conducted to determine the medium lethal concentrations of insecticides after five, ten and twenty generations of selections. The number killed was converted to $\%$ mortality and subjected to probit analysis to determine $\mathrm{LC}_{50}$ values.

Resistance risk assessment was made by calculating realized heritability $\left(\mathrm{h}^{2}\right)$ values as described by Tabashnik (1992).

$\mathrm{h}^{2}=\mathrm{R} / \mathrm{S}$ where $\mathrm{R}$ is the response and $\mathrm{S}$ is the selection differential (Hartl, 1988; Falconer, 1996)

$$
\mathrm{R}=\frac{\log \left(\text { Final } \mathrm{LC}_{\underline{50}}\right)-\log \left(\text { initial } \mathrm{LC}_{\underline{\underline{50}}}\right)}{\mathrm{n}}
$$

Where final $\mathrm{LC}_{50}$ is the $\mathrm{LC}_{50}$ of the offspring after ' $n$ ' generations of selection and initial LC50is the $\mathrm{LC}_{50}$ of the parental generation before ' $n$ ' generations of selection.

$\mathrm{S}=\mathrm{i} \sigma \mathrm{p}$ where ' $\mathrm{i}$ ' is the intensity of selection and ' $\boldsymbol{\sigma} \mathrm{p}$ ' is the phenotypic standard deviation. Intensity of selection (i) was estimated from $p$, which is the \% of the population with values above the selection threshold using appendix of Falconer (1996), based on the properties of normal population. 
The phenotypic standard deviation $(\sigma \mathrm{p})$ was estimated as the reciprocal of the mean of the estimated slopes of profit regression lines (Finney, 1971) from the parental selection before insecticidal selection (initial slope) and the offspring after ' $n$ ' generations of selection (final slope).

$\sigma \mathrm{p}=1 / 2(\text { initial slope }+ \text { final slope })^{-1}$

\section{Results and Discussion}

\section{Selection of resistance to monocrtophos}

The median lethal concentrations of monocrotophos after selection pressure for several generations are shown in the Table 1. The LC50 value gradually increased from 3.639 to $202.89 \mathrm{ppm}$, it was highest in the $30^{\text {th }}$ generation. When the resistant ratios were worked, it was observed that the resistant strain showed 55.89 folds resistance to monocrotophos.

\section{Selection of resistance to dicofol}

The median lethal concentrations of dicofol after selection pressure for several generations are shown in the Table 2. The LC50 value gradually increased from 0.867 to 20.533 ppm. The highest LC50 value of 20.533 was recorded in the $40^{\text {th }}$ generation which was equivalent to 23.59 folds resistance. From the above data it was evident that $N$. longispinosus developed resistance to monocrotophos very rapid compared to dicofol.

\section{Realized heritability $\left(\mathrm{h}^{2}\right)$}

The realized heritability of the susceptible and the resistant strains is provided in the Table 3 . The estimated $\mathrm{h}^{2}$ for the monocrotophos resistant population was 0.09 and 0.16 for generations $F_{0}$ to $F_{5}$ and $F_{10}$ to $F_{20}$ generations, respectively and estimated $h^{2}$ for dicofol resistant population was 0.01 and 0.04 for the $F_{0}$ to $F_{5}$ and $F_{10}$ to $F_{20}$ generations, respectively. The $\mathrm{R}$ and $\mathrm{S}$ were higher in the first five generations compared with the second $F_{10}$ to $F{ }_{20}$ generations in both monocrtophos and dicofol resistant strains. Therefore, the estimated $\mathrm{h} 2$ in both the strains was higher in the second i.e from $\mathrm{F}_{10}$ to $\mathrm{F}_{20}$ than in the first five generations i.e. From the Table 3, it was analysed that the $h^{2}$ value estimated at the end of six generations for monocrotophos selected population $\left(\mathrm{F}_{0}\right.$ to $\left.\mathrm{F}_{5}\right)$ was 1.8 times less than that of $F_{10}$ to $F_{20}$ generations and it was four times less for dicofol resistant population at the end of six generations when compared to $F_{10}$ to $F_{20}$ generations.

Table.1 Median lethal concentrations of monocrotophos to $N$. longispinosus during different generations of selection

\begin{tabular}{|c|c|c|c|c|}
\hline Generations & Chi square (DF) & Slope & LC50 (ppm) & Resistant ratios \\
\hline $\mathbf{0}$ & $0.146(4)$ & $\hat{\mathrm{Y}}=-0.6621+1.1803 \mathrm{X}$ & 3.639 & - \\
\hline $5^{\text {th }}$ & $1.846(4)$ & $\hat{\mathrm{Y}}=-0.8424+0.7956 \mathrm{X}$ & 11.449 & 3.15 \\
\hline $\mathbf{1 0}^{\text {th }}$ & $2.656(4)$ & $\hat{\mathrm{Y}}=-1.2599+1.1451 \mathrm{X}$ & 12.598 & 3.47 \\
\hline $\mathbf{2 0 ^ { \text { th } }}$ & $5.738(4)$ & $\hat{\mathrm{Y}}=-1.9731+0.9817 \mathrm{X}$ & 102.325 & 28.19 \\
\hline $30^{\text {th }}$ & $4.406(4)$ & $\hat{\mathrm{Y}}=-1.8372+0.7963 \mathrm{X}$ & 202.888 & 55.89 \\
\hline $\mathbf{4 0}$ & $6.738(4)$ & $\hat{\mathrm{Y}}=-1.5835+0.6949 \mathrm{X}$ & 189.916 & 52.32 \\
\hline
\end{tabular}


Table.2 Median lethal concentrations of dicofol to $N$. longispinosus during different generations of selection

\begin{tabular}{|c|c|c|c|c|}
\hline Generations & Chi square (DF) & Slope & LC50 (ppm) & Resistant ratios \\
\hline $\mathbf{0}$ & $0.669(4)$ & $\hat{\mathrm{Y}}=0.6671+1.0782 \mathrm{X}$ & 0.867 & - \\
\hline $5^{\text {th }}$ & $1.073(4)$ & $\hat{\mathrm{Y}}=-0.0314+1.3031 \mathrm{X}$ & 1.057 & 1.22 \\
\hline $\mathbf{1 0}^{\text {th }}$ & $0.694(4)$ & $\hat{\mathrm{Y}}=-0.3876+1.0079 \mathrm{X}$ & 2.424 & 2.796 \\
\hline $\mathbf{2 0}^{\text {th }}$ & $1.546(4)$ & $\hat{\mathrm{Y}}=-0.8114+0.7723 \mathrm{X}$ & 11.237 & 12.92 \\
\hline $\mathbf{3 0}^{\text {th }}$ & $0.198(4)$ & $\hat{\mathrm{Y}}=-1.3797+1.0835 \mathrm{X}$ & 18.769 & 21.57 \\
\hline $\mathbf{4 0}^{\text {th }}$ & $4.602(4)$ & $\hat{\mathrm{Y}}=-1.1889+0.9059 \mathrm{X}$ & 20.533 & 23.59 \\
\hline
\end{tabular}

Table.3 Realized heritability $\left(\mathrm{h}^{2}\right)$ of insecticide resistance in the phytoseiid mite $N$. longispinosus

\begin{tabular}{|c|c|c|c|c|c|c|c|c|c|c|}
\hline \multirow[t]{2}{*}{$\begin{array}{l}\text { No. of } \\
\text { generations }\end{array}$} & \multicolumn{3}{|c|}{$\begin{array}{l}\text { Estimate of mean } \\
\text { response per } \\
\text { generation }\end{array}$} & \multicolumn{6}{|c|}{$\begin{array}{c}\text { Estimate of mean selection differential per } \\
\text { generation }\end{array}$} & \multirow[t]{2}{*}{$\mathbf{h}^{2}$} \\
\hline & $\begin{array}{l}\text { Initial } \\
\mathrm{LC}_{50} \\
(\log )\end{array}$ & $\begin{array}{l}\text { Final } \\
\mathrm{LC}_{50} \\
(\log )\end{array}$ & $\mathrm{R}$ & $\mathrm{P}$ & I & $\begin{array}{l}\text { Initial } \\
\text { slope }\end{array}$ & $\begin{array}{l}\text { Final } \\
\text { slope }\end{array}$ & $\sigma^{2}$ & S & \\
\hline \multicolumn{11}{|c|}{ Monocrotophos } \\
\hline $\mathrm{F}_{0}$ to $\mathrm{F}_{5}$ & 0.56 & 1.06 & 0.08 & 44.87 & 0.90 & 1.18 & 0.8 & 1.01 & 0.91 & 0.09 \\
\hline$F_{10}$ to $F_{20}$ & 1.10 & 2.00 & 0.08 & 68.5 & 0.52 & 1.14 & 0.98 & 0.94 & 0.49 & 0.16 \\
\hline \multicolumn{11}{|c|}{ Dicofol } \\
\hline$F_{0}$ to $F_{5}$ & -0.06 & 0.02 & 0.01 & 32.80 & 1.15 & 1.08 & 1.30 & 0.84 & 0.97 & 0.01 \\
\hline$F_{10}$ to $F_{20}$ & 0.38 & 1.00 & 0.05 & 41.73 & 0.97 & 1.00 & 0.77 & 1.13 & 1.09 & 0.04 \\
\hline $\begin{array}{l}R=\text { Response to } \\
=\text { percentage su } \\
=\text { intensity of se }\end{array}$ & $\begin{array}{l}\text { lection } \\
\text { vival } \\
\text { ction }\end{array}$ & & & $\begin{array}{l}\text { henoty } \\
\text { lection } \\
\text { eritabil }\end{array}$ & $\begin{array}{l}\text { stand } \\
\text { eren }\end{array}$ & deviati & & & & \\
\hline
\end{tabular}

Table.4 Degree of dominance in strains of $N$. longispinosus resistant to monocrotophos and dicofol
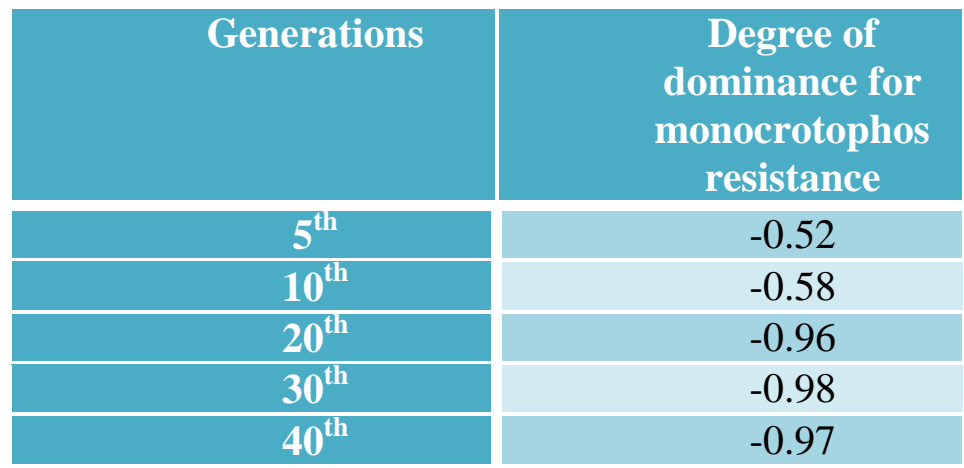

\begin{tabular}{|c|}
\hline $\begin{array}{l}\text { Degree of } \\
\text { dominance for } \\
\text { dicofol } \\
\text { resistance }\end{array}$ \\
\hline-1.0 \\
\hline-1.0 \\
\hline-1.0 \\
\hline-1.0 \\
\hline-1.0 \\
\hline
\end{tabular}




\section{Degree of dominance}

The degree of dominance of resistance is represented in the Table 4 . The degree of dominance of the resistant trait in the strains of $N$. longispinosus selected for monocrotophos was $-0.52,-0.58,-0.96,-0.98$, and -0.97 for $5^{\text {th }}$, $10^{\text {th }}, 20^{\text {th }}, 30^{\text {th }}$ and $40^{\text {th }}$ generations and the degree of dominance for dicofol resistant strain was -1 for all the generations. These estimates of degree of dominance in this study indicated that insecticide resistance is nearly completely recessive.

In this study, the selection of $N$. longispinosus with monocrotophos and dicofol after 40 generations resulted in the development of high resistance (55.89 and 23.59 folds, respectively). Evolution of resistance occurs faster under high selection pressure when susceptible genes are replaced by the resistant genes, resulting in a number of high resistant individuals (Ijaz et. al., 2016). The value of realized heritability obtained at the end of 6 generations $\left(\mathrm{F}_{0}-\mathrm{F}_{5}\right)$ of monocrtophos and dicofol -selected strains is less (1.8 and 4 times) than those for $F_{10}-F_{20}$ generations and could indicate a less level of risk in the development of resistance to monocrotophos and dicofol, initially. The high levels of resistance to monocrotophos and dicofol can only be realized after long periods of selections (10 generations) in the laboratory reared populations of phytoseiid mite, $N$. longispinosus. One of the important uses of heritability estimates is the prediction of future response (Hartl, 1988; Falconer, 1996). The purpose of resistance risk assessment is to predict the rate of development of resistance in response to insecticide application (Via, 1986; Firko and Hayes, 1991). Heritability estimate after one generation of selection is often a reliable approximation of the heritability of the trait in the parental population because laboratory environment has minimal effects (Tabashnik, 1992). As the mean response for the $F_{0}$ to $F_{5}$ generations is less in case of monocrotophos and dicofol, the risk for development of resistance is less during earlier generations. As the selection progresses, high risk in the development of resistance was achieved. Almost 40 generations were required to develop 53-fold increase in LC50 of monocrotophos and 23.59 fold increase was observed in $\mathrm{LC}_{50}$ of dicofol. The differences in the folds of increase might due to the fact that the dicofol being an absolute acaricide affects the growth and survival of phytoseiid mites.

The degree of dominance in this study indicated that insecticide resistance is nearly completely recessive (Table 4). This pattern results from the additive inheritance of multiple genes (Keena and Granett, 1990). The inheritance of insecticide resistance according to Raymond et al. (1987) was controlled by multiple genes in the early generations under continuous selection pressure while single gene in the later generations. According to Lande's (1981) formula the insecticide resistance against monocrotophos and dicofol was controlled by more than 1 gene. Roush and McKenzie (1987) noted that the insecticide resistance is caused by allelic variants at one or two loci. They reasoned that the laboratory selected populations for any insecticide is favoured by multiple gene resistance due to the usage of small size population for the experiment where as under field condition when large population of mites is constantly exposed to an insecticide, the resistance development is favoured by a single gene of rare alleles. Without suitable genetic markers, only with the use of bioassays it is highly difficult to discriminate between inheritance mediated by a single gene and multiple genes and is almost impossible with overlapping concentration-response lines (Tsukamoto, 1963).

It can be concluded that although high levels of resistance were achieved by these laboratoryselected populations, one cannot expect the same under field or polyhouse conditions. This is because the field populations are usually more heterogeneous and exhibit more complex and diverse response to insecticide pressures. Interactions among environment, population structure and selection intensity greatly affect the field response (Bloch and Wool, 1994). The 
evolution of insecticide resistance under field conditions could be delayed due to immigration of susceptible populations from other crops and the alteration of insecticides. The degree of insecticide resistance has been shown to reduce down when the insecticide pressure is removed (Servín-Villegas et al., 2001).

\section{References}

Bloch, G., and Wool, D. 1994. Methidathion resistance in the sweet potato whitefly (Aleyrodidae: Homoptera) in Israel: Selection, heritability and correlated changes of esterase activity. J. Econ. Entomol. 87:1147-1156.

Falconer, D. S., 1996. Introduction to quantitative genetics, $4^{\text {th }}$ ed. Longman, New York pp.480

Finney, D. J., 1971. Probit Analysis. 3rd Edn., Cambridge University Press, London, UK., pp: 76-80.

Firko, M. J., and Hayes, J. L. 1991. Quantitative genetic analysis of larval resistance to cypermethrin in tobacco budworm (Lepidoptera: Noctuidae). J. Econ. Entomol. 84: 34-40.

Hartl, D. L., 1988. A primer of population genetics. 2nd ed. Sinaur, Sunderland, MA. Pp. 181.

Keena, M. A., and Granett, J. 1990. Genetic analysis of propargite resistance in Pacific spider mites and two spotted spider mites (Acari: Tetranychidae). J. Econ. Entomol. 83: 655-661.

Lande, R., 1981. The minimum number of genes contributing to quantitative variation between and within populations. Genetics. 99:541-553.

Raymond, M., Pasteur N., and Georghiou, G. P.
1987. Inheritance of chlorpyrifos resistance in Culex pipiens L. (Diptera: Culicidae) and estimation of the number of genes involved. Heredity. 58:351-356.

Roush, R. T., and McKenzie, J. A. 1987. Ecological genetics of insecticide and acaricide resistance. Ann. Rev. Entomol. 32: 361-380.

Servin-Villegas, R., E. Troyo-Dieguez and J.L. Martinez-Carrillo, 2001.Wild hosts of Bemisia argentifolii bellows and perring in semiarid Northwest Mexico. Southwestern Entomol.,26:239-244.

Sinaver, Sunderland, Massachusetts, 1988.A Primer of Population Genetics. 2nd Edn., Sinaver, Sunderland, Massachusetts, USA.

Tabashnik, B.E., 1991. Determining the mode of inheritance of pesticide resistance with backcross experiments. J. Econ. Entomol., 84: 703-712.

Tabashnik, B.E., 1992. Resistance risk assessment: Realized heritability of resistance to Bacillus thuringiensis in diamondback moth (Lepidoptera: Plutellidae), tobacco budworm (Lepidoptera: Noctuidae) and colorado potato beetle (Coleoptera: Chrysomelidae). J. Econ. Entomol., 85: 1551-1559.

Tsukamoto, M., 1963. The log dosage-probit mortality curve in genetic researches of insect resistance to insecticides.BotyuKagaku, 28: 91-98.

Via, S., 1986. Quantitative genetic models and the evolution of pesticide resistance. Proceedings of the Pesticide Resistance: Strategies and Tactics for Management, (PRSTM'86), National Academy, Washington DC., USA., pp: 222-235.

\section{How to cite this article:}

Sugeetha, G., N.S. Pankaja, D.S. Janardhan and Mahadeva, J. 2018. Resistant Risk Assessment in the Insecticide Resistant Strains of Predatory Mite, Neoseiulus (=Amblyseius) longispinosus (Evans). Int.J.Curr.Microbiol.App.Sci. 7(12): 169-174. doi: https://doi.org/10.20546/ijcmas.2018.712.022 